\title{
Calcified tissue histochemistry: from microstructures to nanoparticles
}

\section{E. Bonucci}

Department of Experimental Medicine and Pathology, La Sapienza University, Rome, Italy

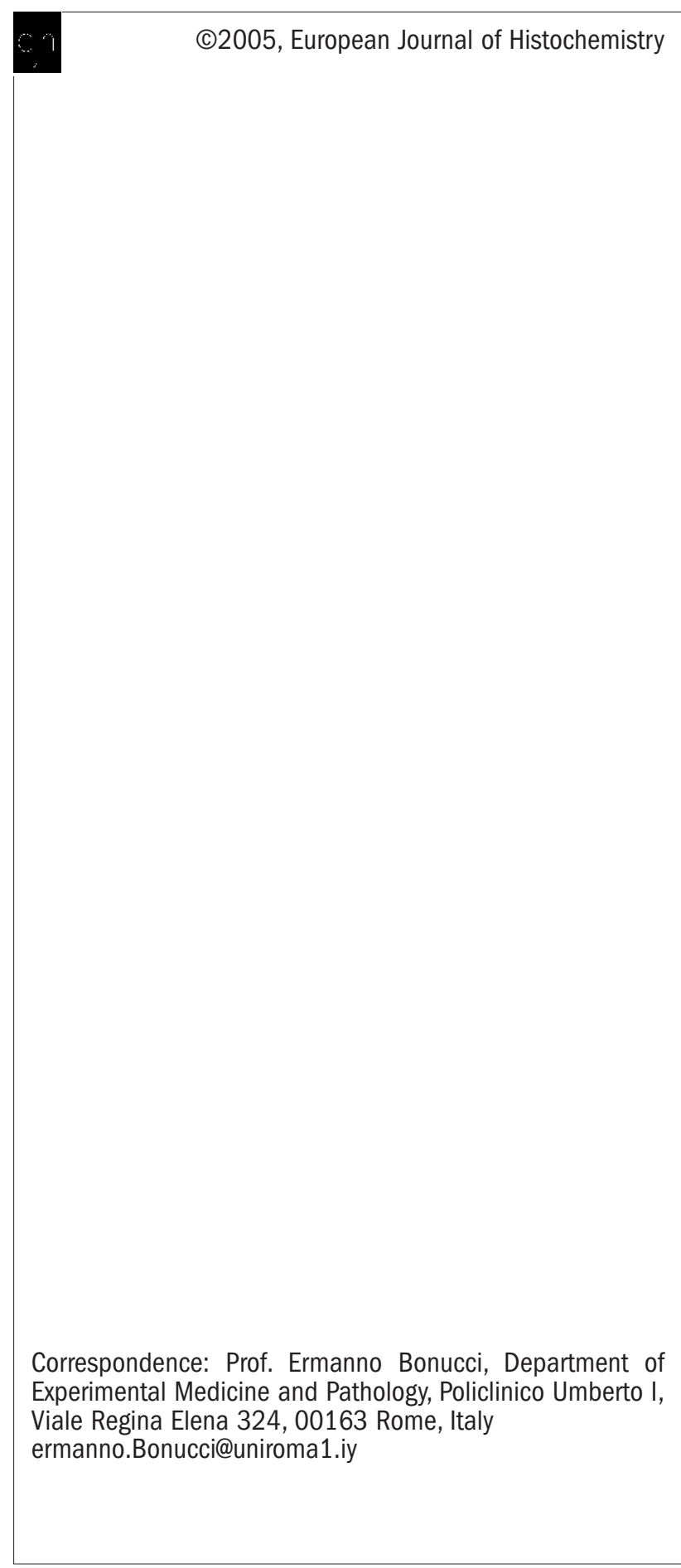

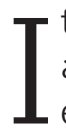
t has long been recognized that histochemistry and cytochemistry offer the only ways of gathering information about the biochemical composition of tissues and cells without disrupting their microscopic architecture. A variety of methods have been put forward for studying nuclei acids, proteins, carbohydrates, lipids, enzymes and other components of intact tissues and cells. By now, many of these have only a historical interest. Some do, however, survive in microscopic and ultramicroscopic applications, and have become incorporated in the most refined and precise techniques that are currently available. Histochemical reactions range from the classic procedures carried out on histological sections to yield final stained products recognizable under the light microscope (Figure 1), to those which are applied on ultrathin sections, using heavy metals or other electron-dense compounds to reveal specific components under the electron microscope (Figure 2A); others range from procedures based on the antigen-antibody reaction that are capable of revealing the presence of specific biological molecules (Figure 2B), to the biophysical techniques which permit the qualitative and quantitative analysis of elements (Figure 3); lastly, there are the recently proposed ultra-high resolution methods that allow nanoparticles to be recognized. This brief review, which is based on personal experience and on the data in the literature, will discuss the most important methods now being used.

Calcified tissues consist of specific cells and an organic matrix that occupies more space than cellular elements and whose outstanding feature is that of being the site where calcification takes place. In bone, the most often studied of all calcified tissues, the most typical component of the organic matrix is type I collagen. Other less well represented constituents are non-collagenous proteins, proteoglycans and lipids bearing traces of enzymes and growth factors. Inorganic structures, whose biophysical characteristics approach those of hydroxy- 


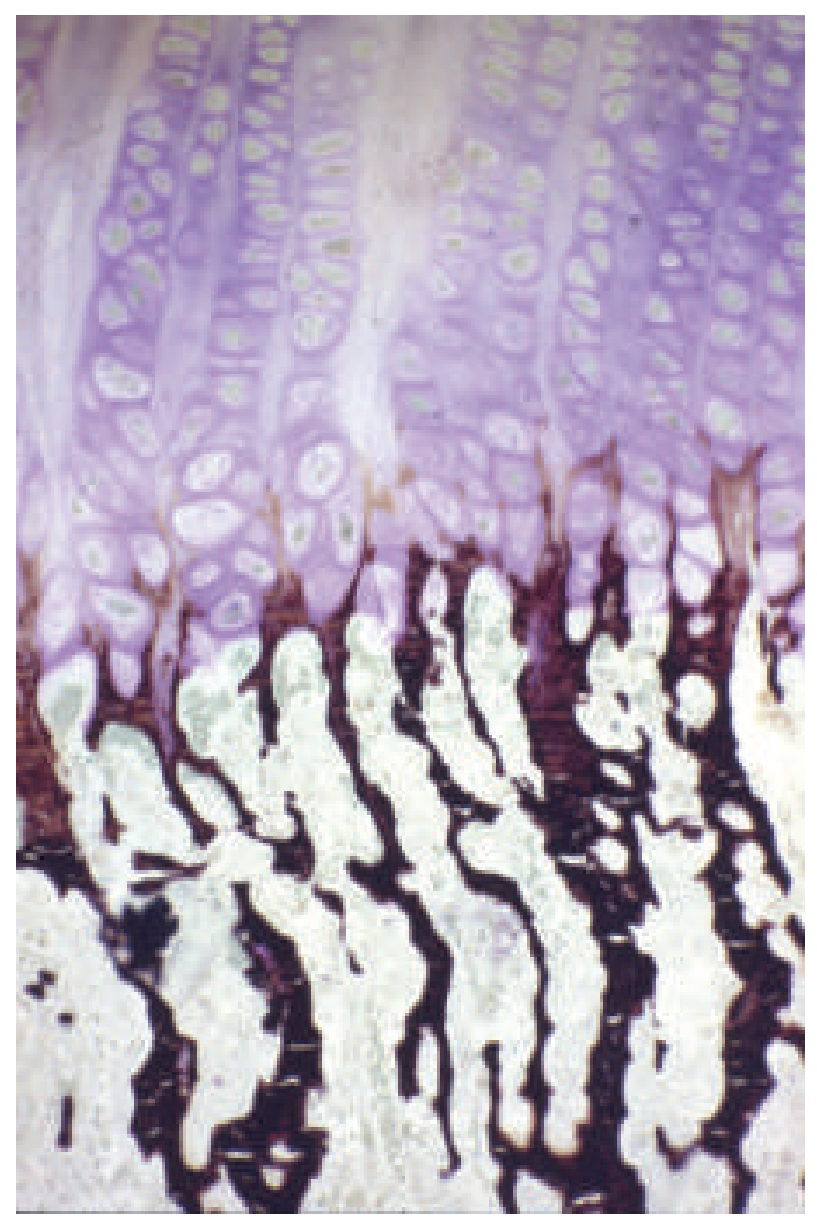

Figure 1. Histological section of the epiphyseal cartilage and metaphyseal trabeculae of the rat; von Kossa staining. The positivity (black stain) of the hypertrophic-degenerated cartilage and of metaphyseal trabeculae documents the presence of calcium phosphate in calcified areas. x 60 .

apatite, and for this reason are named crystals or crystallites, are enmeshed in the matrix and are very closely connected with its organic components. Matrices of other calcified tissues (cartilage, dentin, enamel, cementum, as well as mollusc shells, crustacean exoskeletons, spicules of sea urchin embryos, several unicellular organisms and pathologically calcified tissues) differ in their composition but all basically consist of an organic matrix permeated by inorganic substance (see Bonucci 1992a).

One of the histochemical reactions most often applied to the study of the calcification process explores alkaline phosphatase activity. Long considered responsible for phosphate accumulation in areas of early calcification (Robison 1923; Majno and Rouiller 1951), without ever being assigned a precise functional role (Whyte 1989), alkaline phosphatase is a membrane-bound enzyme typically expressed in osteoblasts and chondrocytes (Doty and Schofield 1976) but present in almost all calcifying areas (de Bernard et al., 1986) and closely correlated with the calcification process itself (Gomez and Boyde 1994). It can be studied in histological sections using Gomori's method (Majno and Rouiller 1951), one of whose modifications, based on the use of cerium (Robinson and Karnovsky 1983; Van Goor et al., 1989; Bonucci et al., 1992; Hulstaert et al., 1992), can be used to localize enzymatic activity under the electron microscope. By applying this method, alkaline phosphatase activity has been demonstrated not only on the osteoblast membrane, but extracellularly too, in areas of calcification (Bonucci et al., 1992) and, most clearly, in matrix vesicles, where the enzyme is the most typical marker (Ali et al., 1970; Matsuzawa and Anderson 1971; McLean et al., 1987). Alkaline phosphatase can be studied using immunohistochemical techniques under the light or the electron microscope (De Bernard et al., 1986; Bruder and Caplan 1990; Masuhara et al., 1992; Morris et al., 1992).

Other often applied histochemical methods aim to study the presence of glycoproteins and acid proteoglycans in histological sections of calcified tissues and their changes as calcification proceeds. Glycoproteins are typically shown by the periodic acid-Schiff (PAS) method, which is based on the production of aldehyde groups by periodate oxidation of vicinal hydroxyl groups and on their staining by Schiff's reagent (Puchtler et al., 1974). The diffuse PAS-positivity of the cartilage matrix and the osteoid border in bone are well-established findings (Cabrini 1961), and glycoproteins are supposed to play a direct role in calcification (de Bernard et al., 1977; Addadi et al., 1989) in all calcifying matrices, from vertebrates to invertebrates (Termine et al., 1981; Butler et al., 1985; Goldberg and Septier 1986; Nanci et al., 1989; Albeck et al., 1996; Marxen et al., 1998; Wilt 1999; LeviKalisman et al., 2001). PAS-like methods can be applied in ultrastructural studies of glycoproteins by using, rather than Schiff's reagent, aldehydereactive electron-dense compounds such as alkaline bismuth (Ainsworth et al., 1972) or thiocarbohydrazide-silver proteinate (Scherft 1970; Spicer and Schulte 1982). In electron microscopy, acidic phosphotungstic acid can be used to identify glycoproteins along cell membranes (Marinozzi 1967; Barsotti and Marinozzi 1980) and in calcifying areas (Bonucci and Gherardi 1975; Bonucci 
2002). There is a rich literature on the histochemistry of acidic proteoglycans in calcified tissues, reflecting the interest these substances have always raised in relation to biological calcification (reviewed by Kobayashi 1971, Buckwalter 1983, Takagi 1990, Shepard 1992). They have long been considered to have a prominent, but still imprecisely known, role in the process: some authors (reviewed by Schubert and Pras 1968; Takagi et al., 1984) see them as promoting calcification, others (Blumenthal et al., 1979) as inhibiting it, and their function may well vary according to whether they are immobilized on a substrate or free in solution (Linde et al., 1989), according to their state of aggregation and the hydrodynamic size of their molecules (Chen et al., 1984), or according to their calcium phosphate content (Schubert and Pras 1968). Under the light microscope, their acidic character is exploited to demonstrate them through the reaction of their acid groups with cationic dyes (Szirmai 1963). In this context, Alcian blue is probably the most often used dye (Quintarelli et al., 1964), but other cationic molecules can be utilized, so giving rise to a metachromatic (Toluidine blue) or basophilic reaction with acid proteoglycans (Cabrini 1961). The link between the strongly positively-charged colloidal iron and acid proteoglycans can be demonstrated under the light microscope through its reaction with potassium ferrocyanide and the formation of Prussian blue and, under the electron microscope, by the intrinsic iron electron density (Figure 2A).

Actually, some of the methods routinely used to show the presence of specific substances in histological sections by light microscopy can be applied to show the same substances in ultrathin sections by electron microscopy. This is true not only of colloidal iron (Curran et al., 1965; Matukas et al., 1967; Takagi et al., 1982), but also of other cationic, electron-dense molecules which react with acid proteoglycans, such as ruthenium red, cationized ferritin, tannic acid-uranyl acetate (Spicer and Schulte 1982), colloidal thorium dioxide (Scherft and Moskalewski 1984), and bismuth nitrate (Smith 1970). These substances have been applied to the study of the calcification process in bone, cartilage, dentin and other hard tissues (Kobayashi 1971). A proportion of the acid proteoglycans may be lost during fixation, so better results are obtained when they are used in tissues that have been fixed with cetylpyridinium chloride-glutaralde- hyde (Eisenstein et al., 1971; Chardin et al., 1990; Hirabayashi et al., 1995), ruthenium red (Nuehring et al., 1991), cationic dye-formaldehyde or -glutaraldehyde (Hunziker and Schenk 1987; Takagi 1990; Shepard 1992), or when cryopreservation methods are used (high pressure freezing, freeze substitution, and low temperature embedding; discussed by Hunziker and Schenk 1984). These methods, in fact, stabilize the proteoglycan molecules so that, even if they collapse during fixation by tissue soaking in aldehyde solutions and take on a granular shape (Matukas et al., 1967), they keep their original, extended, filament-like shape when they are stabilized by cations (Shepard 1992) or are cryopreserved (Hunziker and Schenk 1984, 1987; Hunziker and Herrmann 1990).

Acid proteoglycans in calcified tissues have also been studied with immunohistochemical methods

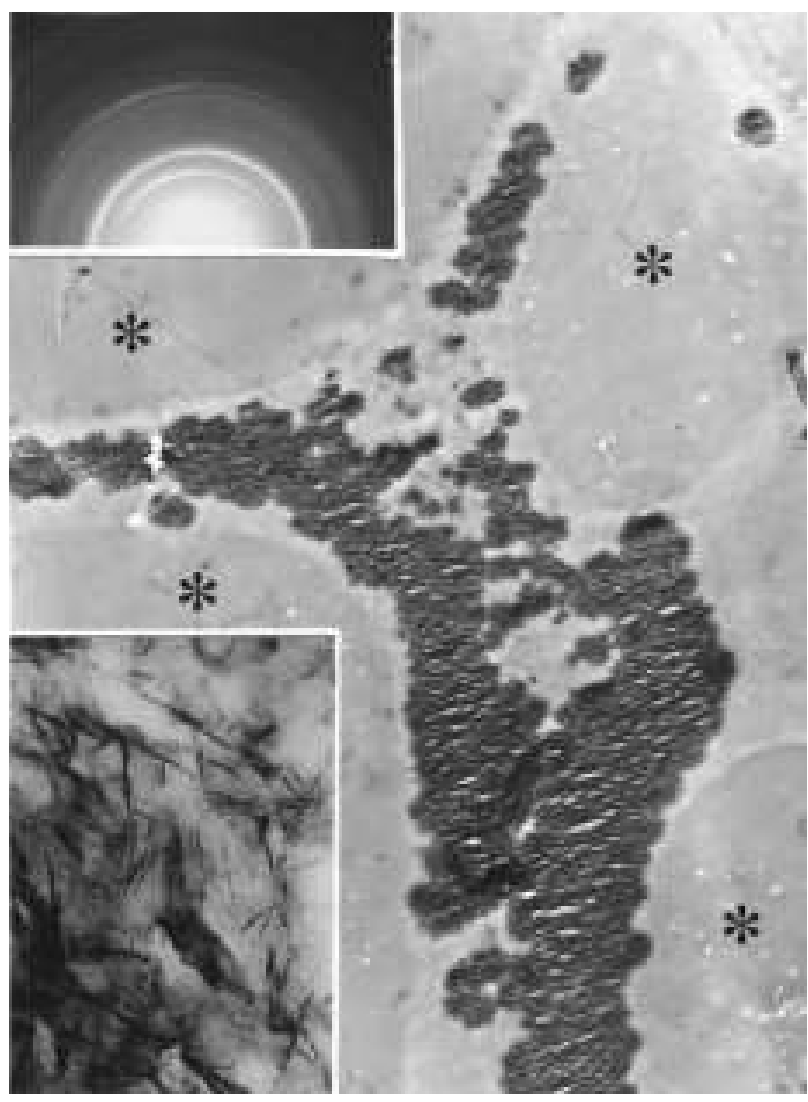

Figure 2. Electron microscopy of an unstained section of epiphyseal cartilage: the inorganic substance appears as an electron-dense material located in intercellular matrix; asterisks show chondrocyte lacunae. $x \mathbf{7 , 5 0 0}$. Upper inset: electron diffraction of the same calcified area; the diffractogram shows that the inorganic substance is hydroxyapatite-like and that it probably consists of needle-shaped crystalline nanoparticles. Lower inset: The enlargment of the electron microscope picture confirms that the calcified areas contain needle-shaped nanoparticles. x 145,000. 


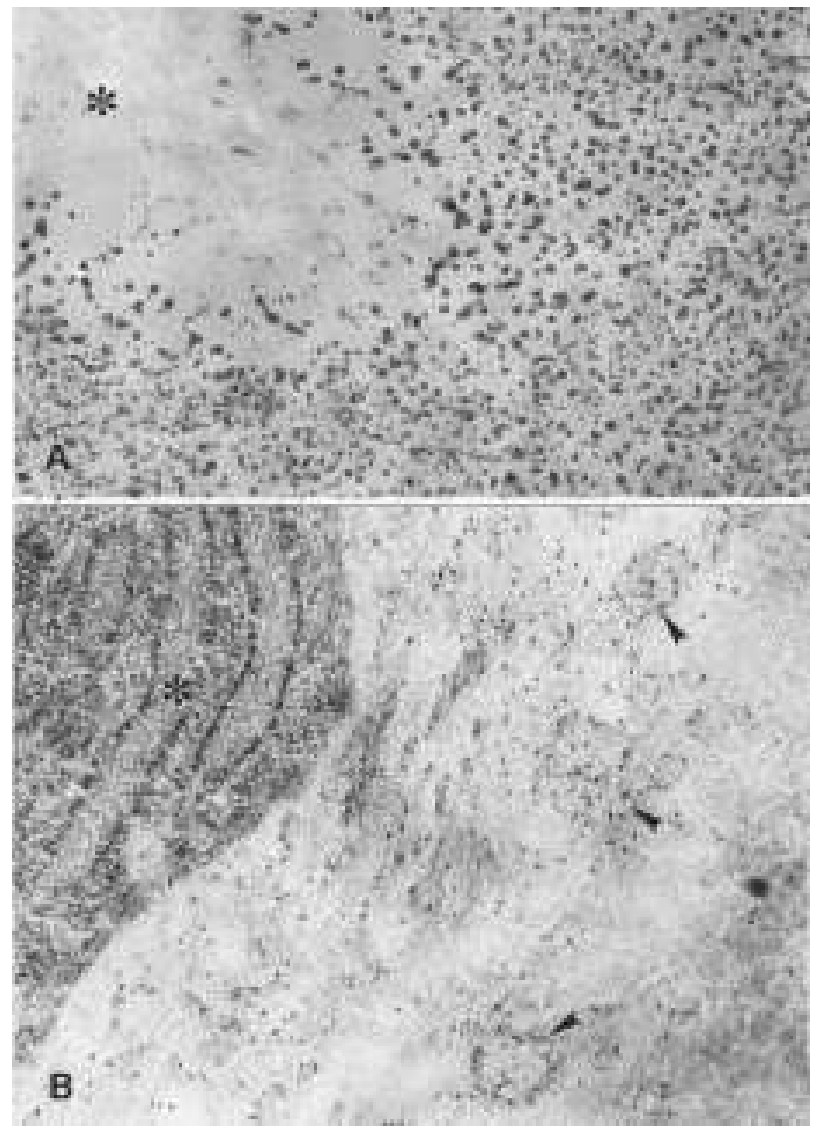

Figure 3. Different ways of showing acid proteoglycans under the electron microscope. A) Matrix of epiphyseal cartilage stained with colloidal iron at pH 2.8; iron 'stains' acid proteoglycans which appear as granular structures because their molecules collapsed during specimen fixation and dehydration. The asterisk shows a chondrocyte lacuna. X 20,000. B) Immunohistochemistry of an area of ossification; CS-56 monoclonal antibody immunospecific for the glycosaminoglycan portion of chondroitin sulfate: immunospecific gold particles are present in the uncalcified osteoid matrix and in that of early areas of calcification (calcification nodules; arrowheads). The asterisk shows part the cytoplasm of an osteoblast. X 25,000.

both under the light and the electron microscope (Figure 2B). A fall in the protein-polysaccharide content of cartilage before or during calcification has been shown with fluorescein-labeled antibodies by Hirschman and Dziewiatkowski (1966). The antibody CS-56 has been used to show chondroitin sulfate distribution in epiphyseal cartilage and to document its absence in the proliferative zone (Nakano et al., 1996). The same antibody has been used to verify the presence of chondroitin sulfate in cartilage calcification nodules under the electron microscope using colloidal gold post-embedding immunocytochemistry (Bonucci and Silvestrini 1992). The monoclonal antibody 2-B-6, which specifically recognizes chondroitin-4-sulfate or dermatan sulfate after digestion with chondroitinase
ABC in RHT-fixed, LR-White-embedded tissues, has been used to show their distribution in cartilage (Hagiwara 1992) and in dentin (Septier et al., 1998). Antibodies are also available for the localization of biglycan (Takagi et al., 2000) and keratan sulfate (Daugaard et al., 1991; Nakano et al., 1996). Immunohistochemical studies of Nakamura et al., (2001) have shown the presence of keratan sulfate around matrix vesicles and in calcification nodules of the rat calvarium.

The so-called non-collagenous proteins are the components within calcifying matrices to which the interest of investigators is at present primarily directed. They comprise a wide group of mostly phosphorylated (acidic), glycoprotein molecules whose inappropriate, generic denomination possibly derived from a wish to stress that bone calcification was not exclusively due to collagen fibrils, so countering a widespread view of that period, and that specific (non-collagenous) proteins of the matrix may also have a role in the process. Whatever their generic name, proteins of that type have been found in all calcifying tissues and, although their role is still uncertain, many believe they are the main regulators of the calcification process (reviewed by De Bernard 1982; Butler et al., 1985; Fisher and Termine 1985; Boskey 1989; Bonucci 2000). This view is supported not only by their presence in tissues, such as tooth enamel or mollusc shells, which contain no collagen fibrils, but, above all, by their affinity for calcium ions (calcium-binding proteins) and by their close connection with inorganic substance in calcified areas. They can, in fact, only be totally extracted from the calcified matrix after this has been decalcified (Linde et al., 1980; Termine et al., 1980, 1981). They can be studied with immunohistochemical methods (Bianco 1990) and a number of antibodies directed to specific proteins are now available. The immunoreaction can be carried out on histological sections, where it can easily be recognized either by fluorescence, if an antibody linked to a fluorochrome has been used, or by the development of a stained product, if the antibody has been linked to an enzyme such as peroxidase or alkaline phosphatase. Immunoreaction can also be applied to thin sections for electron microscopy, mostly using the protein A-colloidal gold method (McKee and Nanci 1995) or the enzymes reported above, and/or can be carried out by non-morphological methods such as immunoblotting (Nanci et al., 1998; Fukae et al., 2001). 
Using these and other types of immunoreaction, a number of proteins thought to have a role in calcification have been detected in calcified matrices (Bronckers et al., 1989; Bianco 1990). The main ones found in bone are osteocalcin, osteonectin, osteopontin (OPN), bone sialoprotein (BSP) and bone acidic glycoprotein-75 (BAG-75). Except for the first, these are all phosphorylated glycoproteins. Their role in calcification is still under discussion; it is interesting, however, that three of them, OPN, BSP and BAG-75 co-localize in calcification nodules, i.e., areas of initial calcification which develop in the osteoid tissue (Bianco et al., 1993; Riminucci et al., 1995; Nanci 1999). They are also found in cement lines (Chen et al., 1994).

Similar proteins are found in other calcified tissues. A highly phosphorylated protein, called phosphophoryn, has been demonstrated in dentin (Dimuzio and Veis 1978), where its concentration appears to be directly related to the amount of mineral (Rahima et al., 1988); its concentration is, in fact, high at the predentin-dentin interface but gradually falls in passing towards the enamel (Nakamura et al., 1985). No collagen fibrils are present in enamel matrix, which consists of noncollagenous proteins only (for review see Nanci 2003). These are highly acidic proteins tightly bound to enamel crystals. They can be divided into two groups, amelogenins and nonamelogenins; the latter include ameloblastin (also named amelin, or sheathlin), tuftelin, enamelin and a $65 \mathrm{kDa}$ glycoprotein. With enamel maturation, they undergo progressive extracellular proteolysis, which characterizes various stages of enamel development and ultimately leads to their almost complete disappearance, as shown both by extraction methods and immunohistochemistry (Blumen and Merzel 1972; Nanci et al., 1992; Nanci et al., 1994; Smith and Nanci 1996). Mineral-bound glycoproteins are also found in the matrix of mollusc shells (Travis and Gonsalves 1969; Wheeler 1992; Sudo et al., 1997) and other calcified structures of invertebrates (Benson and Wilt 1992; Wilt et al., 2003).

Besides collagen fibers and non-collagenous proteins, other organic components can be found in calcifying matrices. These include lipids, which have long been known to occur in calcifying areas, where they are so strongly bound to the inorganic substance that a fraction of them can only be extracted after decalcification (Shapiro 1970a; Shapiro 1970b). First shown histochemically in calcifying cartilage (Irving 1960), their presence as acidic phospholipids has been confirmed under the electron microscope in cartilage (Bonucci and Silvestrini 1994) and in bone (Takahashi et al., 1991; Nefussi et al., 1992; Bonucci and Silvestrini 1995). They have also been demonstrated in dentin fixed in the presence of malachite green (Goldberg and Septier 1985) or treated with iodoplatinate (Vermelin et al., 1994), and in cartilage and bone fixed with malachite green and treated with the phospholipase A2-gold method (Silvestrini et al., 1996). The results of these investigations, in agreement with those of biochemical studies (Peress et al., 1974; Wuthier 1975; Wuthier and Gore 1977; Wu et al., 2002), have shown that lipids are contained in matrix vesicles. Calcium-acidic phospholipid-phosphate complexes are formed which may initiate the calcification process in cartilage (Boskey et al., 1980) and bone (Boskey and Posner 1976; Boskey et al., 1982), as well as in unicellular organisms (Boyan et al., 1984) and pathological vascular calcification (Dmitrovsky and Boskey 1985). Phospholipids have been shown immunohistochemically in cartilage and bone (Bonucci et al., 1997) and in dentin matrix vesicles (Tsuji et al., 1994) using the MC22-33F monoclonal antibody, which specifically reacts with choline-containing phospholipids (Mark et al., 1992).

Considering that the most distinctive feature of the calcified matrices is that they contain inorganic substance, it is hardly surprising that this has been the topic of a large number of studies. Over a long period these studies have mainly been based on $X$-ray diffraction, which has shown that the inorganic substance of bone and other calcified tissues is hydroxyapatite. This technique (Finean and Engström 1953; Carlström and Finean 1954), along with electron microscopy (Bocciarelli 1970; Ascenzi et al., 1978; Jackson et al., 1978), suggested that apatite appears in bone as very thin, needle- or platelet-like crystals (reviewed by Elliott 1973). These structures (shown in Figure 2, inset) are, however, poorly crystallized and highly impure and, especially at the earliest stage of formation, show very little crystal arrangement (Bachra 1967), so it has been suggested that they are paracrystalline structures comparable with biopolymers (Wheeler and Lewis 1977; Arnold et al., 2001). Possibly for this reason, they have been called mineralites instead of crystallites (Eppell et al., 2001; Tong et al., 2003). 
Several highly refined techniques, some of which allow nanoparticles and atoms to be detected, have been used to study the problem of the structure and composition of the earliest inorganic particles and their relationships with organic components. These techniques have the disadvantage of being rather complex and not available in all laboratories, but they yield important results, ranging from the high spatial resolution of element distribution to the evaluation of the local concentration of nanoparticles and single elements, from the assessment of the degree of crystallinity to the appraisal of macromolecular crystals at subnanometer resolution, and from mapping specific molecules to imaging protein surface and membrane components. An excellent example of what these techniques can achieve is the images of individual aggregans macromolecules and their constituent glycosaminoglycan chains obtained by $\mathrm{Ng}$ et al., (2003) using atomic force microscopy.

Some of these method are longstanding, others are new. The list is quite long. Mentioning only the most important ones, they comprise wide (Engfeldt et al., 1985) and small (Fratzl et al., 1991) angle $X$-ray diffraction and synchrotron radiation (Ascenzi et al., 1985); selected area electron diffraction (shown in Figure 2, inset; Landis and Glimcher 1978; Arnold et al., 1999); neutron diffraction (Wenk and Heidelbach 1999; Girardin et al., 2000); electron spin resonance spectrometry (Ostrowski et al., 1972; Roufosse et al., 1976; Ascenzi et al., 1977); energy dispersive $\mathrm{X}$-ray elemental analysis, otherwise known as electron-probe analysis (Lewinson and Silbermann 1990); energyfiltering electron microscopy (Egerton 2003; Leapman 2003); infrared spectroscopy (Paschalis et al. 1996; Pleshko et al., 1991); and atomic force microscopy (Reich et al., 2001; Santos and Castanho 2004), besides other biophysical techniques. Taken together, these methods have produced an impressive corpus of data which, together with those obtained using histochemical (Brighton and Hunt 1976; Appleton and Morris 1979; Morris and Appleton 1980; Lewinson and Silbermann 1990) and autoradiographic (Lacroix 1960; Nagai and Frank 1974) procedures that aim to determine the movements of calcium and phosphate ions within, and their binding to, the organic matrix, have contributed a great deal to knowledge of the physiopathology of bone and other calcified tissues. The fine structure and composition of the earliest inor- ganic particles are, however, still uncertain and so far even the availability of techniques as sophisticated as these has failed to produce a definitive explanation of the way inorganic substance is actually deposited in the matrix.

Many of the difficulties encountered springs from the close relationship that links inorganic and organic substance. The former masks the latter, which can, in its turn, hinder detection of the former. The merging of these two components often makes it imperative to prepare for morphological studies by using decalcification to unmask the organic matrix. Regrettably, decalcification disrupts the structure of the calcified matrix (reviewed by Callis and Sterchi 1998). Several methods have been proposed to preclude the extraction artefacts that derive from the removal of inorganic substance and the loss of organic components. The method which appears to yield the best results is known as PEDS (post-embedding decalcification and staining). In this case, sections of embedded tissues are floated on a decalcifying solution before they are stained (Bonucci 1967; Bonucci and Reurink 1978). This leaves the organic components intact, because they are protected against the dangerous effects of decalcification by being embedded in the resin, as shown by their ultrastructure, which is so well preserved that the tissue seems not to have been decalcified at all (Bonucci 1992b). Histochemical and immunohistochemical reactions are possible after PEDS, provided that the embedding resin is appropriate (Bonucci and Gherardi 1975; Bonucci et al., 1986, 1988, 1989; Goldberg et al., 1980).

The results of PEDS confirm that the inorganic and organic substance are closely linked in all calcified tissues and suggest that the earliest inorganic particles, rather than being true crystals, are organic-inorganic, crystal-like structures whose formation and shape derive directly from the template role of organic molecules (reviewed by Bonucci 2002). The biochemical, histochemical and immunohistochemical detection of acidic, phosphorylated glycoproteins in many, if not all, calcified matrices, and their very close relationship with the inorganic substance, have brought with them a new attitude to the way crystals are formed, about the mechanism of their maturation, and about the way these proteins could trigger the process. Much remains to be done, especially on the function of single proteins and the relationship between them. 
In this connection, the possibility of using transgenic, knock-out or null animal models opens up new, promising perspectives (Boskey 1998).

\section{Acknowledgements}

Personal studies mentioned in this review have been carried out with the financial support of the University of Rome La Sapienza, the Italian National Reserach Council (CNR) and the Ministry of .The author is indebted to Giuliana Silvestrini, Paola Ballanti, Carlo Della Rocca, Silvia Berni for their excellent scientific collaboration.

\section{References}

Addadi L, Berman A, Moradian Oldak J, Weiner S. Structural and stereochemical relations between acidic macromolecules of organic matrices and crystals. Connect Tissue Res 1989; 21:127-35.

Ainsworth SK, Ito S, Karnovsky MJ. Alkaline bismuth reagent for high resolution ultrastructural demonstration of periodate-reactive sites. J Histochem Cytochem 1972; 20:995-1005.

Albeck S, Addadi L, Weiner S. Regulation of calcite crystal morphology by intracrystalline acidic proteins and glycoproteins. Connect Tissue Res 1996; 35:365-70.

Ali SY, Sajdera SW, Anderson HC. Isolation and characterization of calcifying matrix vesicles from epiphyseal cartilage. Proc Natl Acad Sci 1970; 67:1513-20.

Appleton J, Morris DC. The use of the potassium pyroantimonate-osmium method as a means of identifying and localizing calcium at the ultrastructural level in the cells of calcifying system. J Histochem Cytochem 1979; 27:676-80.

Arnold S, Plate U, Wiesmann H-P, Straatmann U, Kohl H, Höhling HJ. Quantitative analyses of the biomineralization of different hard tissues. J Microsc 2001; 202:488-94.

Arnold S, Plate U, Wiesmann H-P, Stratmann U, Kohl H, Höhling H-J. Quantitative electron spectroscopic diffraction analyses of the crystal formation in dentine. J Microsc 1999; 195:58-63.

Ascenzi A, Bigi A, Koch MH, Ripamonti A, Roveri N. A low-angle Xray diffraction analysis of osteonic inorganic phase using synchrotron radiation. Calcif Tissue Int 1985; 37:659-64.

Ascenzi A, Bonucci E, Ostrowski K, Sliwowski A, Dziedzic-Goclawska A, Stachowicz W, Michalik J. Initial studies on the crystallinity of the mineral fraction and ash content of isolated human and bovine osteons differing in their degree of calcification. Calcif Tissue Res 1977; 23:7-11.

Ascenzi A, Bonucci E, Ripamonti A, Roveri N. X-ray diffraction and electron microscope study of osteons during calcification. Calcif Tissue Res 1978; 25:133-43.

Bachra BN. Some molecular aspects of tissue calcification. Clin Orthop 1967; 51:199-222.

Barsotti P, Marinozzi V. PTA staining of osmium-fixed, GMA-embedded tisues. J Submicr Cytol 1980; 12:315-9.

Benson SC, Wilt FH. Calcification of spicules in the sea urchin embryo. In: Bonucci $\mathrm{E}$, ed. Calcification in biological systems. CRC Press, Boca Raton 1992, pp. 157-78.

Bianco P. Ultrastructural immunohistochemistry of noncollagenous

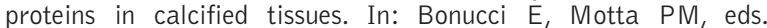
Ultrastructure of skeletal tissues. Kluwer Academic Publishers, Boston 1990, pp. 63-78.

Bianco P, Riminucci M, Silvestrini G, Bonucci E, Termine JD, Fisher LW, Gehron-Robey P. Localization of bone sialoprotein (BSP) to Golgi and post-Golgi secretory structures in osteoblasts and to discrete sites in early bone matrix. J Histochem Cytochem 1993; 41:193-203.

Blumen $G$, Merzel J. The decrease in the concentration of organic material in the course of formation of the enamel matrix. Experientia 1972; 28:545-8
Blumenthal NC, Posner AS, Silverman LD, Rosenberg LC. Effect of proteoglycans on in vitro hydroxyapatite formation. Calcif Tissue Int 1979; 27:75-82.

Bocciarelli DS. Morphology of crystallites in bone. Calcif Tissue Res 1970; 5:261-9.

Bonucci E. Fine structure of early cartilage calcification. J Ultrastruct Res 1967; 20:33-50.

Bonucci E. Calcification in biological systems. CRC Press, Boca Raton,1992a.

Bonucci $E$. Role of collagen fibrils in calcification. In: Bonucci $E_{\text {, ed. }}$ Calcification in biological systems. CRC Press, Boca Raton, 1992b, pp. 19-39.

Bonucci E. Basic composition and structure of bone. In: An YH Draughn RA, eds. Mechanical testing of bone and the bone-implant interface. CRC Press, Boca Raton, 2000, pp. 3-21.

Bonucci E. Crystal ghosts and biological mineralization: fancy spectres in an old castle, or neglected structures worthy of belief? J Bone Miner Metab 2002; 20:249-65.

Bonucci $E$, Bianco $P$, Hayashi $Y$, Termine JD. Ultrastructural immunohistochemical localization of non-collagenous proteins in bone, cartilage and developing enamel. In: Ali SY, ed. Cell mediated calcification and matrix vesicles. Excerpta Medica, Amsterdam, 1986, pp. 33-8.

Bonucci E, Gherardi G. Histochemical and electron microscope investigations on medullary bone. Cell Tissue Res 1975; 163:81-97.

Bonucci E, Reurink J. The fine structure of decalcified cartilage and bone: a comparison between decalcification procedures performed before and after embedding. Calcif Tissue Res 1978; 25:179-90.

Bonucci $E$, Silvestrini G. Immunohistochemical investigation on the presence of chondroitin sulfate in calcification nodules of epiphyseal cartilage. Eur J Histochem 1992; 36:407-22.

Bonucci E, Silvestrini G. Morphological investigation of epiphyseal cartilage after glutaraldehyde-malachite green fixation. Bone 1994; 15:153-60.

Bonucci $E$, Silvestrini $G$. Ultrastructure of rat metaphyseal bone after glutaraldehyde-malachite green fixation. It J Miner Electrol Metab 1995; 9:15-20.

Bonucci E, Silvestrini G, Bianco P. Extracellular alkaline phosphatase activity in mineralizing matrices of cartilage and bone: ultrastructural localization using a cerium-based method. Histochemistry 1992; 97:323-7.

Bonucci E, Silvestrini G, Di Grezia R. The ultrastructure of the organic phase associated with the inorganic substance in calcified tissues. Clin Orthop 1988; 233:243-61.

Bonucci E, Silvestrini G, Di Grezia R. Histochemical properties of the "crystal ghosts" of calcifying epiphyseal cartilage. Connect Tissue Res 1989; 22:43-50.

Bonucci E, Silvestrini G, Mocetti P. MC22-33F monoclonal antibody shows unmasked polar head groups of choline-containing phospholipids in cartilage and bone. Eur J Histochem 1997; 41:177-90.

Boskey AL. Noncollagenous matrix proteins and their role in mineralization. Bone and Mineral 1989; 6:111-23.

Boskey AL. Biomineralization: conflicts, challenges, and opportunities. J Cell Biochem 1998; 30/31:83-91.

Boskey AL, Bullough PG, Posner AS. Calcium-acidic phospholipidphosphate complexes in diseased and normal human bone. Metab Bone Dis Rel Res 1982 ; 4:151-6.

Boskey AL, Posner AS. Extraction of calcium-phospholipid-phosphate complex from bone. Calcif Tissue Res 1976; 19:273-83.

Boskey AL, Posner AS, Lane JM, Goldberg MR, Cordella DM. Distribution of lipids associated with mineralization in the bovine epiphyseal growth plate. Arch Biochem Biophys 1980; 199:305-11.

Boyan BD, Landis WJ, Knight J, Dereszewski G, Zeagler J. Microbial hydroxyapatite formation as a model of proteolipid-dependent membrane-mediated calcification. Scann Electr Microsc 1984; 4:1793800.

Brighton CT, Hunt RM. Histochemical localization of calcium in growth plate mitochondria and matrix vesicles. Feder Proc 1976; 35:143-7.

Bronckers ALJJ, Lyaruu DM, Wöltgens JHM. Immunohistochemistry of extracellular matrix proteins during various stages of dentinogenesis. Connect Tissue Res 1989; 22:65-70.

Bruder SP, Caplan AI. A monoclonal antibody against the surface of osteoblasts recognizes alkaline phosphatase isoenzymes in bone, 


\section{E. Bonucci}

liver, kidney, and intestine. Bone 1990; 11:133-9.

Buckwalter JA. Proteoglycan structure in calcifying cartilage. Clin Orthop 1983; 172:207-32.

Butler WT, Sato S, Rahemtulla F, Prince CW, Tomana M, Bhown M, et al. Glycoproteins of bone and dentin. In: Butler WT, ed. The chemistry and biology of mineralized tissues. EBSCO Media, Birmingham, 1985, 107-12.

Cabrini RL. Histochemistry of ossification. Int Rev Cytol 1961; 2:283306.

Callis G, Sterchi D. Decalcification of bone: literature review and practical study of various decalcifying agents, methods, and their effects on bone histology. J Histotechnol 1998; 21:49-58.

Carlström D, Finean JB. X-ray diffraction studies on the ultrastructure of bone. Biochim Biophys Acta 1954; 13:183-91.

Chardin H, Septier D, Goldberg M. Visualization of glycosaminoglycans in rat incisor predentin and dentin with cetylpyridinium chloride-glutaraldehyde as fixative. J Histochem Cytochem 1990; 38:885-94.

Chen $\mathrm{C}-\mathrm{C}$, Boskey AL, Rosenberg LC. The inhibitory effect of cartilage proteoglycans on hydroxyapatite growth. Calcif Tissue Int 1984; 36:285-90.

Chen J, Mckee MD, Nanci A, Sodek J. Bone sialoprotein mRNA expression and ultrastructural localization in fetal porcine calvarial bone: comparisons with osteopontin. Histochem J 1994; 26:67-78.

Curran RC, Clark AE, Lovell D. Acid mucopolysaccharides in electron microscopy. The use of the colloidal iron method. J Anat 1965; 99:427-34.

Daugaard S, Strange L, Schiodt T. Immunohistochemical staining for chondroitin sulphate and keratan sulphate. An evaluation of two monoclonal antibodies. Histochemistry 1991; 95:585-9.

de Bernard B. Glycoproteins in the local mechanism of calcification. Clin Orthop 1982; 162:233-44.

de Bernard B, Bianco P, Bonucci E, Costantini M, Lunazzi GC, Martinuzzi $P$, et al. Biochemical and immunohistochemical evidence that in cartilage an alkaline phosphatase is a Ca2+-binding glycoprotein. J Cell Biol 1986; 103:1615-23.

de Bernard B, Stagni N, Colautti I, Vittur F, Bonucci E. Glycosaminoglycans and endochondral calcification. Clin Orthop 1977; 126:285-91.

Dimuzio MT, Veis A. Phosphophoryns - Major noncollagenous proteins of rat incisor dentin. Calcif Tissue Res 1978; 25:169-78.

Dmitrovsky $\mathrm{E}$, Boskey AL. Calcium-acidic phospholipid-phosphate complexes in human atherosclerotic aortas. Calcif Tissue Int 1985; 37:121-5.

Doty SB, Schofield BH. Enzyme histochemistry of bone and cartilage cells. Progr Histochem Cytochem 1976; 8:1-38.

Egerton RF. New techniques in electron energy-loss spectroscopy and energy-filtered imaging. Micron 2003; 34:127-39.

Eisenstein R, Sorgente N, Kuettner KE. Organization of extracellular matrix in epiphyseal growth plate. Am J Pathol 1971; 65:515-34.

Elliott JC. The problems of the composition and structure of the mineral components of the hard tissues. Clin Orthop 1973; 93:313-45.

Engfeldt B, Hjerpe A, Reinholt FP, Wikström B. Distribution of matrix vesicles in the lower part of the epiphyseal growth plate. In: Butler WT, ed. The chemistry and biology of mineralized tissues. Ebsco Media, Inc., Birmingham, AL, 1985, pp. 356-9.

Eppell SJ, Tong W, Katz JL, Kuhn L, Glimcher MJ. Shape and size of isolated bone mineralites measured using atomic force microscopy. J Orthop Res 2001; 19:1027-34.

Finean JB, Engström A. The low-angle scatter of x-rays from bone tissue. Biochim Biophys Acta 1953; 11:178-89.

Fisher LW, Termine JD. Noncollagenous proteins influencing the local mechanisms of calcification. Clin Orthop 1985; 200:362-85.

Fratzl P, Fratzl-Zelman N, Klaushofer K, Vogl G, Koller K. Nucleation and growth of mineral crystals in bone studied by small-angle $\mathrm{X}$-ray scattering. Calcif Tissue Int 1991; 48:407-13.

Fukae M, Tanabe T, Yamakoshi Y, Yamada M, Ujiie Y, Oida S. Immunoblot detection and expression of enamel proteins at the apical portion of the forming root in porcine permanent incisor tooth germs. J Bone Miner Metab 2001; 19:236-43.

Girardin E, Millet P, Lodini A. X-ray and neutron diffraction studies of crystallinity in hydroxyapatite coatings. J Biomed Mater Res 2000; 49:211-5.

Goldberg M, Noblot MM, Septier D. Effets de deux méthodes de démineralisation sur la préservation des glycoprotéines et des protéoglycanes dans les dentines intercanaliculaires et péricanaliculaires chez le cheval. Jour Biol Buccale 1980; 8:315-30.

Goldberg M, Septier D. Improved lipid preservation by malachite green-glutaraldehyde fixation in rat incisor predentine and dentine. Archs Oral Biol 1985; 30:717-26.

Goldberg M, Septier D. Ultrastructural location of complex carbohydrates in developing rat incisor enamel. Anat Record 1986; 216:181-90.

Gomez S, Boyde A. Correlated alkaline phosphatase histochemistry and quantitative backscattered electron imaging in the study of rat incisor ameloblasts and enamel mineralization. Microsc Res Techn 1994; 29:29-36.

Hagiwara H. Immunoelectron microscopic study of proteoglycans in rat epiphyseal growth plate cartilage after fixation with ruthenium hexamine trichloride (RHT). Histochemistry 1992; 98:305-9.

Hirabayashi Y, Fujii T, Yamada K. The histochemical visualization of proteoglycan molecules in tracheal cartilage of the rat. Acta Histochem Cytochem 1995; 28:305-9.

Hirschman A, Dziewiatkowski DD. Protein-polysaccharide loss during endochondral ossification: immunochemical evidence. Science 1966; 154:393-5.

Hulstaert CE, Halbhuber K-J, Kalicharan D. Electron microscopical demonstration of alkaline phosphatase activity with the ceriumbased method in citrate-containing medium at $\mathrm{pH} 9.3$ and the influence of glutaraldehyde fixation. Cell Molec Biol 1992; 38:545-52.

Hunziker EB, Herrmann W. Ultrastructure of cartilage. In: Bonucci E, Motta PM, eds. Ultrastructure of skeletal tissues. Kluwer Academic Publishers, Boston, 1990, pp. 79-109.

Hunziker EB, Schenk RK. Cartilage ultrastructure after high pressure freezing, freeze substitution, and low temperature embedding. II. Intercellular matrix ultrastructure - Preservation of proteoglycans in their native state. J Cell Biol 1984; 98:277-82.

Hunziker EB, Schenk RK. Structural organization of proteoglycans in cartilage. In: Wight TN, Mecham $P$, eds. Biology of proteoglycans. Academic Press, Orlando (FL), 1987, pp. 155-85.

Irving JT. Histochemical changes in the early stages of calcification. Clin Orthop 1960; 17:92-102.

Jackson SA, Cartwright AG, Lewis $D$. The morphology of bone mineral crystals. Calcif Tissue Res 1978; 25:217-22.

Kobayashi S. Acid mucopolysaccharides in calcified tissues. Int Rev Cytol 1971; 30:257-371.

Lacroix P. $\mathrm{Ca}^{45}$ autoradiography in the study of bone tissue. In: Rodahl $\mathrm{K}$, Nicholson JT, Brown EM, eds. Bone as a tissue. McGraw-Hill, New York, 1960, pp. 262-79.

Landis WJ, Glimcher MJ. Electron diffraction and electron probe microanalysis of the mineral phase of bone tissue prepared by anhydrous techniques. J Ultrastruct Res 1978; 63:188-223.

Leapman RD. Detecting single atoms of calcium and iron in biological structures by electron energy-loss spectrum-imaging. J Microsc 2003; 210:5-15.

Levi-Kalisman Y, Falini G, Addadi L, Weiner S. Structure of the nacreous organic matrix of a bivalve mollusk shell examined in the hydrated state using cryo-TEM. J Struct Biol 2001; 135:8-17.

Lewinson D, Silbermann M. Ultrastructural localization of calcium in normal and pathologic cartilage. In: Bonucci E, Motta PM, eds. Ultrastructure of skeletal tissues. Kluwer Academic Publishers, Boston, 1990, pp. 129-52.

Linde A, Bhown M, Butler WT. Noncollagenous proteins of dentin. A re-examination of proteins from rat incisor dentin utilizing techniques to avoid artifacts. J Biol Chem 1980; 255:5931-42.

Linde A, Lussi A, Crenshaw MA. Mineral induction by immobilized polyanionic proteins. Calcif Tissue Int 1989; 44:286-95.

Majno G, Rouiller ChDie alkalische Phosphatase in der Biologie des Knochengewebes. Histochemische Untersuchungen. Virchows Arch 1951; 321:1-61.

Marinozzi V. Réaction de l'acide phosphotungstique avec la mucine et les glycoprotéines des plasmamembranes. J Microscopie 1967); $6: 68$ A.

Mark MP, Tsuji T, Portoukalian J, Rebbaa A, Zidan G, Ruch J-V. Characterization of a monoclonal antibody that specifically binds to choline phospholipids and its use in immunocytochemistry. J Histochem Cytochem 1992; 40:827-38.

Marxen JC, Hammer M, Gehrke T, Becker W. Carbohydrates of the 
organic shell matrix and the shell-forming tissue of the snail Biomphalaria glabrata (say). Biol Bull 1998; 194:231-40.

Masuhara K, Suzuki S, Yoshikawa H, Tsuda T, Takaoka K, Ono K, et al. Development of a monoclonal antibody specific for human bone alkaline phosphatase. Bone and Mineral 1992; 17:182-6.

Matsuzawa T, Anderson HC. Phosphatases of epiphyseal cartilage studied by electron microscopic cytochemical methods. J Histochem Cytochem 1971; 19:801-9.

Matukas VJ, Panner BJ, Orbison JL. Studies on ultrastructural identification and distribution of protein-polysaccharide in cartilage matrix. J Cell Biol 1967; 32:365-77.

McKee MD, Nanci A. Postembedding colloidal-gold immunocytochemistry of noncollagenous extracellular matrix proteins in mineralized tissues. Microsc Res Techn 1995; 31:44-62.

McLean FM, Keller PJ, Genge BR, Walters SA, Wuthier RE. Disposition of preformed mineral in matrix vesicles. Internal localization and association with alkaline phosphatase. J Biol Chem 1987; 262:10481-8

Morris DC, Appleton J. Ultrastructural localization of calcium in the mandibular condylar growth cartilage of the rat. Calcif Tissue Int 1980; 30:27-34.

Morris DC, Masuhara K, Takaoka K, Ono K, Anderson HC. Immunolocalization of alkaline phosphatase in osteoblasts and matrix vesicles of human fetal bone. Bone and Mineral 1992; 19:287-98

Nagai N, Frank RM. Electron microscopic autoradiography of Ca45 during dentinogenesis. Cell Tissue Res 1974; 155:513-23.

Nakamura $H$, Hirata A, Tsuji T, Yamamoto T. Immunolocalization of keratan sulfate proteoglycan in rat calvaria. Arch Histol Cytol 2001; 64:109-18.

Nakamura 0, Gohda E, Ozawa M, Senba I, Miyazaki H, Murakami T, et al. Immunohistochemical studies with a monoclonal antibody on the distribution of phosphophoryn in predentin and dentin. Calcif Tissue Int 1985; 37:491-500.

Nakano T, Sim JS, Imai S, Koga T. Lack of chondroitin sulphate epitope in the proliferating zone of the growth plate of chicken tibia. Histochem J 1996; 28:867-73.

Nanci A. Content and distribution of noncollagenous matrix proteins in bone and cementum: relationship to speed of formation and collagen packing density. J Struct Biol 1999; 26:256-69.

Nanci A. Ten Cate's oral histology: Development, structure, and function, Sixth Edition, Mosby, St. Louis, 2003.

Nanci A, Ahluwalia JP, Zalzal S, Smith CE. Cytochemical and biochemical characterization of glycoproteins in forming and maturing enamel of the rat incisor. J Histochem Cytochem 1989; 37:161933.

Nanci A, Kawaguchi H, Kogaya Y. Ultrastructural studies and immunolocalization of enamel proteins in rodent secretory stage ameloblasts processed by various cryofixation methods. Anat Record 1994; 238:425-36

Nanci A, McKee MD, Smith CE. Immunolocalization of enamel proteins during amelogenesis in the cat. Anat Rec 1992; 233:335-49.

Nanci A, Zalzal S, Lavoie P, Kunikata M, Chen W-Y, Krebsbach PH, et al. Comparative immunochemical analyses of the developmental expression and distribution of ameloblastin and amelogenin in rat incisors. J Histochem Cytochem 1998; 46:911-34.

Nefussi J-R, Septier D, Sautier J-M, Forest N, Goldberg M. Localization of malachite green positive lipids in the matrix of bone nodule formed in vitro. Calcif Tissue Int 1992; 50:273-82.

$\mathrm{Ng} \mathrm{L}$, Grodzinsky AJ, Patwari P, Sandy J, Plaas A, Ortiz C. Individual cartilage aggregan macromolecules and their constituent glycosaminoglycans visualized via atomic force microscopy. J Struct Biol 2003; 143:242-57.

Nuehring LP, Steffens WL, Rowland GN. Comparison of the ruthenium hexammine trichloride method to other methods of chemical fixation for preservation of avian physeal cartilage. Histochem J 1991; 23:201-14

Ostrowski K, Dziedzic-Goclawska A, Stachowicz W, Michalik J. Sensitivity of the electron spin resonance technique as applied in histochemical research on normal and pathological calcified tissues. Histochemie 1972; 32:343-51.

Paschalis EP, DiCarlo E, Betts F, Sherman P, Mendelsohn R, Boskey AL. FTIR microspectroscopic analysis of human osteonal bone. Calcif Tissue Int 1996; 59:480-7.
Peress NS, Anderson HC, Sajdera SW. The lipids of matrix vesicles from bovine fetal epiphyseal cartilage. Calcif Tissue Res 1974; 14:275-81.

Pleshko N, Boskey A, Mendelsohn R. Novel infrared spectroscopic method for the determination of crystallinity of hydroxyapatite minerals. Biophys J 1991; 60:786-93.

Puchtler $\mathrm{H}$, Meloan SN, Brewton BR. On the binding of Schiff's reagent in the PAS reaction: effects of molecular configurations in models. Histochemistry 1974; 40:291-9.

Quintarelli G, Scott JE, Dellovo MC. The chemical and histochemical properties of alcian blue II. Dye binding of tissue polyanions. Histochemie 1964; 4:86-98.

Rahima M, Tsay T-G, Andujar M, Veis A. Localization of phosphophoryn in rat incisor dentin using immunocytochemical techniques. J Histochem Cytochem 1988; 36:153-7.

Reich Z, Kapon R, Nevo R, Pilpel Y, Zmora S, Scolnik Y. Scanning force microscopy in the applied biological sciences. Biotechnol Adv 2001 19:451-85.

Riminucci M, Silvestrini G, Bonucci E, Fisher LW, Gehron Robey P, Bianco P. The anatomy of bone sialoprotein immunoreactive sites in bone as revealed by combined ultrastructural histochemistry and immunohistochemistry. Calcif Tissue Int 1995; 57:277-84.

Robinson JM, Karnovsky MJ. Ultrastructural localization of several phosphatases with cerium. J Histochem Cytochem 1983; 31:1197208.

Robison R. The possible significance of hexosephosphoric esters in ossification. Biochem J 1923; 17:286-93.

Roufosse A, Richelle LJ, Gilliam OR. Electron spin resonance of organic free radicals in dental enamel and other calcified tissues. Archs Oral Biol 1976; 21:227-32.

Santos NC, Castanho MARB. An overview of the biophysical applications of atomic force microscopy. Biophys Chem 2004; 107:133-49.

Scherft JP. An electron microscopic investigation into the possible presence of periodic acid reactive polysaccharides in the matrix of calcified cartilage and bone. Koninkl Nederland Akad Wetensh 1970; 73:414-21.

Scherft JP, Moskalewski S. The amount of proteoglycans in cartilage matrix and the onset of mineralization. Metab Bone Dis Rel Res 1984; 5:195-203.

Schubert M, Pras M. Ground substance proteinpolysaccharides and the precipitation of calcium phosphate. Clin Orthop 1968; 60:235-55.

Septier D, Hall RC, Lloyd D, Embery G, Goldberg M. Quantitative immunohistochemical evidence of a functional gradient of chondroitin 4-sulphate/dermatan sulphate, developmentally regulated in the predentine of rat incisor. Histochem J 1998; 30:275-84.

Shapiro IM. The phospholipids of mineralized tissues I. Mammalian compact bone. Calcif Tissue Res 1970a; 5:21-9.

Shapiro IM. The phospholipids of mineralized tissues II. Elasmobranch and teleost skeletal tissues. Calcif Tissue Res 1970b; 5:30-8

Shepard N. Role of proteoglycans in calcification. In: Bonucci E, ed. Calcification in biological systems. CRC Press, Boca Raton, 1992 pp. 41-58.

Silvestrini G, Zini N, Sabatelli $P$, Mocetti $P$, Maraldi N M, Bonucci E. Combined use of malachite green fixation and PLA2-gold complex technique to localize phospholipids in areas of early calcification of rat epiphyseal cartilage and bone. Bone 1996; 18:559-65.

Smith CE, Nanci A. Protein dynamics of amelogenesis. Anat Record 1996; 245:186-207.

Smith JW. The disposition of protein-polysaccharide in the epiphyseal plate cartilage of the young rabbit. J Cell Sci 1970; 6:843-64.

Spicer SS, Schulte BA. Ultrastructural methods for localizing complex carbohydrates. Human Pathol 1982; 13:343-54.

Sudo S, Fujikawa T, Nakagura T, Ohkubo T, Sakaguchi K, Tanaka M, et al. Structures of mollusc shell framework proteins. Nature 1997; 387:563-4.

Szirmai JA. Quantitative approaches in the histochemistry of mucopolysaccharides. J Histochem Cytochem. 1963; 11:24-34.

Takagi M. Ultrastructural cytochemistry of cartilage proteoglycans and their relation to the calcification process. In: Bonucci $\mathrm{E}$, Motta $\mathrm{PM}$, eds. Ultrastructure of skeletal tissues. Kluwer Academic Publishers, Boston, 1990, pp. 111-27.

Takagi M, Kamiya N, Urushizaki T, Tada Y, Tanaka H. Gene expression and immunohistochemical localization of biglycan in association with mineralization in the matrix of epiphyseal cartilage. Histochem 


\section{E. Bonucci}

J 2000; 32:175-86.

Takagi M, Parmley RT, Denys FR, Yagasaki H, Toda Y. Ultrastructural cytochemistry of proteoglycans associated with calcification of shark cartilage. Anat Record 1984; 208:149-58.

Takagi M, Parmley RT, Spicer SS, Denys FR, Setser ME. Ultrastructural localization of acidic glycoconjugates with a low iron diamine method. J Histochem Cytochem 1982; 30:471-6.

Takahashi T, Matsuo M, Takahashi K, Tatsumi J, Ikeda K, Scow R0. An application of malachite green-glutaraldehyde fixative for visualizing lipid droplets in cultured parietal bone cells from fetal mouse. Jap J Oral Biol 1991; 33:196-202.

Termine,J.D.; Belcourt,A.B.; Christner,P.J.; Conn,K.M.; Nylen, M.U. Properties of dissociatively extracted fetal tooth matrix proteins I. Principal molecular species in developing bovine enamel. J Biol Chem 1980; 255:9760-8.

Termine JD, Belcourt AB, Conn KM, Kleinman HK. Mineral and collagen-binding proteins of fetal calf bone. J Biol Chem 1981; 256:10403-8.

Tong W, Glimcher MJ, Katz JL, Kuhn L, Eppell SJ. Size and shape of mineralites in young bovine bone measured by atomic force microscopy. Calcif Tissue Int 2003; 72:592-8.

Travis DF, Gonsalves M. Comparative ultrastructure and organization of the prismatic region of two bivalves and its possible relation to the chemical mechanism of boring. Am Zoolog 1969; 9:635-61.

Tsuji T, Mark MP, Ruch J-V. Immunocytochemical localization of choline-phospholipids in postnatal mouse molars. Archs Oral Biol 1994; 39:81-6.

Van Goor H, Gerrits PO, Hardonk MJ. Enzyme histochemical demonstration of alkaline phosphatase activity in plastic-embedded tissues using a Gomori-based cerium-DAB technique. J Histochem Cytochem 1989; 37:399-403.

Vermelin L, Septier D, Goldberg M. Iodoplatinate visualization of phospholipids in rat incisor predentine and dentine, compared with malachite green aldehyde. Histochemistry 1994; 101:63-72.

Wenk H-R, Heidelbach F. Crystal alignment of carbonated apatite in bone and calcified tendon: results from quantitative texture analysis. Bone 1999; 24:361-9.

Wheeler AP. Mechanisms of molluscan shell formation. In: Bonucci E, ed. Calcification in biological systems. CRC Press, Boca Raton, 1992, pp. 179-216.

Wheeler EJ, Lewis D. An X-ray study of the paracrystalline nature of bone apatite. Calcif Tissue Res 1977; 24:243-8.

Whyte MP. Alkaline phosphatase: physiological role explored in hypophosphatasia. In: Peck WA, ed. Bone and mineral research/6. Elsevier Science Publishers BV, Amsterdam, 1989, pp. 175-218.

Wilt FH. Matrix and mineral in the sea urchin larval skeleton. J Struct Biol 1999; 126:216-26.

Wilt FH, Killian CE, Livingston BT. Development of calcareous skeletal elements in invertebrates. Differentiation 2003; 71:237-50.

Wu LN, Genge BR, Kang MW, Arsenault AL, Wuthier RE. Changes in phospholipid extractability and composition accompany mineralization of chicken growth plate cartilage matrix vesicles. J Biol Chem 2002; 277:5126-33.

Wuthier RE. Lipid composition of isolated epiphyseal cartilage cells, membranes and matrix vesicles. Biochim Biophys Acta 1975; 409:128-43.

Wuthier RE, Gore ST. Partition of inorganic ions and phospholipids in isolated cell, membrane and matrix vesicle fractions: evidence for Ca- $\mathrm{P}_{\mathrm{i}}$-acidic phospholipid complexes. Calcif Tissue Res 1977; 24:163-71. 